\title{
Estimation of Some Immunological and Biochemical in the Patients with Systemic Lupus Erythematosus in Males and Females in Baghdad
}

\author{
Dua'a Akram AL-Atabi', Bushra F. Hasan ${ }^{2}$, Ali H. AL-Hafidh ${ }^{3}$ \\ ${ }^{1}$ Post graduate/ MSc, ${ }^{2}$ Professor, Department of Chemistry, College of Science for Women, University of Baghdad, \\ Iraq, 3 Lecturer/PhD in College of Health And Medical Technology/Baghdad/Iraq
}

\begin{abstract}
Background: Systemic lupus erythematosus (SLE) is the prototypic multisystem autoimmune disease caused by the mistakenly in the body immune system that attacks healthy tissue in many parts of the body. Autoimmune thyroiditis (AT) is an organic-specific disease associated with production of a variety of antibodies such as antinuclear antibodies, anti-double stranded DNA, anti-Ro antibodies and anti-cardiolipin antibodies.

Methods: the study consist of 90 subjects from the both sexes were registered in this study.. The subjects have been divided in to three groups, group one and group two represent the patient groups that include, (30 SLE patients without taking steroid drugs group one (3male-27female) and 30 SLE patients with taking steroid drugs group two (2male-28female) with age range (16-57)years and thirty healthy subjects regards as a control (5male-25female)). Various clinical and laboratory parameters of SLE were measured for each groups. Also thyroid function tests were measured, which included free T3, free T4 and TSH. Antimicrosomal was measured for all groups were estimated by VIDAS method.

Results: the results showed thyroid disorders were common $(23.33 \% \%)$ in lupus patients. Hypothyroidism was the commonest (13.33\%) abnormality in SLE patients then hyperthyroidism (1.66\%). At the same time, the results showed significance decreasing $(p<0.01)$ in level of FT3 in (G1 and G2) when compared with the control group. Also, the results showed high significant decrease $(\mathrm{p}<0.01)$ in level of FT4 in (G2) comparison with both groups (G1) and control group. But, The results showed no significant differences $(\mathrm{P}<0.01)$ in level of TSH comparison with other studies groups included in the study. Further antiTPO a significant increasing $(\mathrm{p}<0.01)$ in $(\mathrm{G} 1)$ comparison with both groups $(\mathrm{G} 2)$ and control group. Then this study revealed a significance increasing of ESR, hsCRP, anti dsDNA, and ANA in both patients groups rather than control group.
\end{abstract}

Keywords: SLE, ESR, hsCRP, ANA, anti dsDNA, FT3, FT4, TSH, antiTPO, VIDAS.

\section{Introduction}

Autoimmune disorders can be broken down into organ-specific and systemic diseases ${ }^{(1)}$. Autoimmune thyroid disease (AITD) is a well-known, organ-specific autoimmune disorder that is associated with many

\section{Corresponding author:}

Dua'a Akram AL-Atabi

duaakram382@gmail.com non-specific autoimmune diseases such as rheumatoid arthritis, Sjögren's syndrome, and SLE ${ }^{(2)}$. AITD represents a group of pathologies characterized by thyroid gland dysfunction due to a loss of immunological tolerance with the presence of cellular and humoral immune response, infiltration of auto-reactive $\mathrm{T}$ cells and $\mathrm{B}$ cells, production of autoantibodies directed against antigens from the gland and, subsequently, the development of clinical manifestations ${ }^{(3,4)}$. Because it is a group of autoimmune diseases (AD) clustered together, 
the clinical heterogeneity is diverse and varies among these diseases, it can be classified according to whether a state of hypothyroidism (i.e., Hashimoto's thyroiditis) or hyperthyroidism [i.e., Graves' disease (GD) ${ }^{(5)}$. These disorders derive from the diverse relationships between environmental and genetic factors ${ }^{(6)}$ and are distinguished by reactivity to auto-thyroid antigens expressed as distinctive autoimmune inflammatory or antireceptor diseases ${ }^{(7,8)}$.

Systemic Lupus Erythematosus (SLE) is characterized by disturbances in the immune response and autoantibody production that lead to the multisystem organ damage and dysfunction ${ }^{(9)}$. The disease is nine times more often observed in women than in men, especially in women at child-bearing years (15 35 years), and is also more common in those of nonEuropean descent ${ }^{(10)}$. Candidate environmental risk factors include UV light exposure, Epstein-Barr virus (EBV) infection, endogenous retroviral sequences and multiple drugs.

The association of thyroid disorders with systemic lupus erythematosus (SLE) has been confirmed ${ }^{(11)}$. Disease activity indexes of SLE disease activity have been described by: SLEDAI. The SLEDAI is a global index that was developed in Toronto in 1986 and described in detail by Bombardier and collaborators in $1992^{(12)}$. The SLEDAI appears sensitive to

change in disease activity over time ${ }^{(13)}$

\section{Subjects and Methods}

The study consisted of 60 patients (30 patients of SLE without taking steroid drugs and 30 patients of SLE with taking steroid drugs) and 30 healthy controls. Their age range was (16-57)years; the sample collected from the Baghdad teaching Hospital/ Medical city Iraq. Blood samples were collected at $(8: 30 \mathrm{am})$, by taking $5 \mathrm{ml}$ of venous blood from each patients and healthy human. Five $\mathrm{ml}$ of blood was taken by using $(5 \mathrm{ml})$ disposable syringe. Two $\mathrm{ml}$ of blood transferred to sodium citrate tubes to measured Erythrocyte Sedimentation Rate (ESR), three $\mathrm{ml}$ transferred into gel Tubes allowed to clot at room temperature for 30 minutes, the sample was centrifuged at $2500 \mathrm{rpm}$ (rotation per minute) for 5 minutes and the serum removed and deposited at $\left(-20^{\circ} \mathrm{C}\right)$ immediately before analyzed the biochemical markers and immunological (FT3, FT4, TSH, anti TPO, and hsCRP) measured by vitek immunodiagnostic assay system (VIDAS). ANA and anti dsDNA measured by enzyme-linked immune sorbent assay (ELISA) based on biotin double antibody sandwich technology.

Exclusion criteria: The patients who are under Chemotherapy, The patients who already has thyrotoxic, and patients with vasculitis disease were excluded from the current study.

\section{Statistical Analysis}

The program Statistical Analysis System- SAS (2012) was used to detect the effect of difference factors in the parameters of the study. The least significant difference - LSD test (Variation Analysis-ANOVA) has been used to make significant comparisons between means. The chi-square method was used to greatly equate the proportion (probability 0.05 and 0.01 ). Estimation of coefficient of association between parameters of variance in this analysis.

\section{Results}

The mean age of patients in G1 was $(31.06 \pm 8.92)$ years while a slightly decrease with the G2 patients $(30.23 \pm 10.25)$ years, and the mean age of control group was $(30.69 \pm 9.54)$ years with P-Value equal to 0.944 . The difference was not significant $(\mathrm{p}>0.05)$ when compared among the groups as shown in table (1). In the same table, according to the gender distribution of patients, there was a higher incidence in female $(90,93.33 \%)$ than male $(10,6.66 \%)$ in $\mathrm{G} 1$ and $\mathrm{G} 2$ respectively. 
Table (1): The demographic data of patients with systemic lupus erythematosus SLE.

\begin{tabular}{|l|l|l|l|l|}
\hline Variables & $\begin{array}{l}\text { Control } \\
\text { N=30 }\end{array}$ & $\begin{array}{l}\text { SLE without taking } \\
\text { steroid drugs G1 } \\
\text { N=30 }\end{array}$ & $\begin{array}{l}\text { SLE with taking steroid } \\
\text { drugs G2 } \\
\text { N=30 }\end{array}$ & P-value \\
\hline $\begin{array}{l}\text { Age (year) (mean } \pm \\
\text { SD) }\end{array}$ & $30.69 \pm 9.54$ & $31.06 \pm 8.92$ & $30.23 \pm 10.25$ & $0.944 \mathrm{NS}$ \\
\hline Gender & $5(16.66 \%)$ & $3(10 \%)$ & $2(6.66 \%)$ & $28(93.33 \%)$ \\
\hline Male & $25(83.33 \%)$ & $27(90 \%)$ & \\
\hline Female &
\end{tabular}

Table (2) shown FT3 values, Mean \pm SD of patients groups, G1, G2, and control group were [(4.33 \pm 1.19$)$,( $2.90 \pm 1.06)$, and $(4.97 \pm 0.57)] \mathrm{pmol} / \mathrm{l}$ with P-Value equal to 0.0001 . The difference was high significant decrease $(\mathrm{p}<0.01)$ in level of FT3 comparison with other studies groups. FT4 [(15.33 \pm 3.76$),(11.22 \pm 2.55)$, and $(15.29 \pm$ 2.51) $\mathrm{pmol} / 1$ with $P-V a l u e$ equal to 0.0001 . The results showed a high significant decrease $(\mathrm{p}<0.01)$ in level of FT4 in G2 compared with both groups G1 and control group. TSH [(3.01 \pm 1.77$),(2.38 \pm 1.82)$, and $(2.11 \pm 1.08)] \mathrm{IU} / \mathrm{ml}$. The results showed no significant differences $(\mathrm{P}<0.01)$ in level of TSH comparison with other studies groups, and antiTPO $[(3.97 \pm 2.23),(2.33 \pm 1.96)$, and $(1.44 \pm 1.32)] \mathrm{IU} / \mathrm{ml}$. The results showed a significant increased $(\mathrm{p}<0.01)$ in level of anti-TPO in G1 comparison with both groups G2 and control group, respectively.

Table (2): Thyroid function test values and antiTPO in patients with Systemic lupus erythematosus (SLE).

\begin{tabular}{|c|c|c|c|c|}
\hline \multirow[b]{2}{*}{ Laboratory variables } & \multicolumn{4}{|l|}{$($ mean \pm SD $)$} \\
\hline & $\begin{array}{l}\text { Control group } \\
\mathbf{N}=\mathbf{3 0}\end{array}$ & $\begin{array}{l}\text { SLE without taking } \\
\text { steroid drugs } G 1 \\
(\mathrm{~N}=\mathbf{3 0})\end{array}$ & $\begin{array}{l}\text { SLE with taking } \\
\text { steroid drugs G2 } \\
(\mathrm{N}=30)\end{array}$ & P-value \\
\hline $\begin{array}{l}\text { T3 } \\
(\mathrm{pmol} / 1)\end{array}$ & $4.97 \pm 0.57 \mathrm{a}$ & $4.33 \pm 1.19 b$ & $2.90 \pm 1.06 \mathrm{c}$ & $0.0001 * *$ \\
\hline $\begin{array}{l}\text { T4 } \\
(\mathrm{pmol} / 1)\end{array}$ & $15.29 \pm 2.51 \mathrm{a}$ & $15.33 \pm 3.76 \mathrm{a}$ & $11.22 \pm 2.55 b$ & $0.0001 * *$ \\
\hline $\begin{array}{l}\text { TSH } \\
\text { ( IU/ml ) }\end{array}$ & $2.11 \pm 1.08 \mathrm{a}$ & $3.01 \pm 1.77 \mathrm{a}$ & $2.38 \pm 1.82 \mathrm{a}$ & $0.0919 \mathrm{NS}$ \\
\hline $\begin{array}{l}\text { Anti-TPO } \\
(\mathrm{IU} / \mathrm{ml})\end{array}$ & $1.44 \pm 1.32 b$ & $3.97 \pm 2.23 \mathrm{a}$ & $2.33 \pm 1.96 b$ & $0.0001 * *$ \\
\hline$* *(\mathrm{P}<0.01), \mathrm{NS}:$ Non- & & & & \\
\hline
\end{tabular}


The results are shown in the table (3) the distribution of the patients with SLE according to results of the thyroid function test. These subgroups are; hypothyroidism group, 8(13.33\%) patients. Hyperthyroidism group, 1(1.66\%). Hashimoto's disease (HD) group, 3(5\%). Subclinical hypothyroidism group, 2(3.33\%).

Table (3): Results Thyroid function test in subgroups of patients with SLE.

\begin{tabular}{|l|l|l|}
\hline \multirow{2}{*}{ Thyroid function subgroups } & \multicolumn{2}{|l|}{ SLE (N=60) } \\
\cline { 2 - 4 } & No. & $\%$ \\
\hline Hypothyroidism & 8 & 13.33 \\
\hline Hyperthyroidism & 1 & 1.66 \\
\hline Hashimoto's disease (HD) & 3 & 5 \\
\hline Subclinical hypothyroidism & 2 & 3.33 \\
\hline
\end{tabular}

Table (4) shows the results of screening and Inflammation markers in both (G1 and G2 and control) groups. The results showed a high significant increase $(\mathrm{p}<0.01)$ in level of ESR, hsCRP, ANA, and dsDNA compared with other studies groups.

Table (4): Comparison between difference groups in screening and Inflammation markers

\begin{tabular}{|l|l|l|l|l|}
\hline $\begin{array}{l}\text { Laboratory variables } \\
\text { (mean } \pm \text { SD) }\end{array}$ & Control group $\mathbf{N = 3 0}$ & $\begin{array}{l}\text { SLE without taking } \\
\text { steroid drugs G1 } \\
\mathbf{( N = 3 0 )}\end{array}$ & $\begin{array}{l}\text { SLE with taking } \\
\text { steroid drugs G2 } \\
\text { (N=30) }\end{array}$ & P-value \\
\hline ESR (mm/h) & $8.88 \pm 0.33 \mathrm{~b}$ & $32.27 \pm 25.53 \mathrm{a}$ & $23.80 \pm 15.26 \mathrm{a}$ & $0.0001^{* *}$ \\
\hline hsCRP $(\mathrm{mg} / \mathrm{L})$ & $0.564 \pm 0.25 \mathrm{c}$ & $3.51 \pm 3.50 \mathrm{a}$ & $2.17 \pm 1.25 \mathrm{~b}$ & $0.0001^{* *}$ \\
\hline ANA (IU/ml) & $0.629 \pm 0.26 \mathrm{c}$ & $2.93 \pm 1.46 \mathrm{a}$ & $2.06 \pm 1.36 \mathrm{~b}$ & $0.0001^{* *}$ \\
\hline dsDNA (IU/ml) & $8.88 \pm 0.33 \mathrm{c}$ & $32.27 \pm 25.53 \mathrm{a}$ & $23.80 \pm 15.26 \mathrm{~b}$ & $0.0001^{* *}$ \\
\hline$* *(\mathrm{P}<0.01)$. & & & & \\
\hline
\end{tabular}

\section{Discussion}

The present work was conducted to study the thyroid dysfunction in SLE patients. sixty patients from Iraqi individuals who attended to Baghdad teaching Hospital/ Medical city Iraq known to have SLE were included in the study, their ages ranged between 16 and 57 years and the mean age were $(31.06 \pm 8.92$, and $30.23 \pm 10.25)$ year in $\mathrm{G} 1$ and $\mathrm{G} 2$ respectively.
Most (91.67\%) of the patients are females. As regard sex, SLE is an autoimmune disease affecting primarily women $^{(14)}$. Our finding is consistent with Franco et al. ${ }^{(15)}$; they noticed that women were $91.8 \%$ and men $8.2 \%$. Also, Khanfir et al. ${ }^{(16)}$ showed that women were $90.3 \%$ and men were $9.7 \%$, with an average age at SLE onset of approximately 30.66 years. Further, Ong et al. ${ }^{(17)}$ found that females were $94.2 \%$ among SLE patients' diagnosed with in age between 15 to 74 year. 
In the current study, we illustrated that the mean values of acute phase reactants were high; ESR at 1st hour and CRP. ESR and CRP become high leveler in the autoimmune disease than malignancy or infection and rheumatoid arthritis SLE patients revealed high ESR and CRP, but ESR increase in infection and lupus, therefore it a non-specific marker for differentiating between the diseases. $^{(18)}$.

The results in this study show SLE patients that taking steroid drugs have more thyroid diseases when compared with the SLE patients without taking steroid drugs due to the effect taking steroid drugs, the glucocorticoid inhibits the enzyme T4 5'-deiodinas, which regulates the extra thyroidal production of $\mathrm{T} 3$ from $\mathrm{T} 4^{(19)}$.

In this study, we reported distribution of the patients with SLE according to their thyroid dysfunction and thyroid function test results, $23.33 \%$ of SLE patients had abnormal thyroid function. Our result regarding thyroid dysfunction is agree with Zakeri and Sandooghi ${ }^{(20)}$; they showed that $24.1 \%$ prevalence of thyroid disorders. Our result was lower than El-Azizl et al ${ }^{(21)}$ they showed that $33.3 \%$ prevalence of thyroid disorders.

Our patients in the thyroid dysfunction group were hypothyroidism group, $8(13.33 \%)$ patients. Hyperthyroidism group, 1(1.66\%). Hashimoto's disease (HD) group, 3(5\%). Subclinical hypothyroidism group, $2(3.33 \%)$. The occurrence of hypothyroidism is common in SLE, a large body of data has support this $^{(1)}$. Our results were comparable to El-Azizl et $\mathrm{al}^{(21)}$. they observed that in their SLE group; were $10.0 \%$ subclincal hypo-thyroidisim, $6.6 \%$ biochemical hypothyroidisim, $10.0 \%$ euthyroid sick syndrome, $3.3 \%$ subclincal hyperthyroidisim, and 3.3\% biochemical hyperthyroidisim. Also, Chan et al. ${ }^{(22)}$ noticed that $4.3 \%$ of their SLE patients had clinical hypothyroidism. Mader et al. ${ }^{(23)}$ as well, cleared that $11.6 \%$ of their SLE patients had clinical hypothyroid compared to $1.9 \%$ in the control group. Variable results were reported in many studies; Hypothyroidism and hyperthyroidism prevalence ranged from $3.9 \%$ to $39 \%$ and $0.0 \%$ to $10.9 \%$, respectively. $(24,25,26,27)$.

\section{Conclusion and Recommendation}

Thyroid disorders are common in patients suffering from SLE. The most common form is hypothyrodism. Patients with SLE should be assessed for thyroid disorder by testing for early detection of thyroid abnormalities FT3, FT4, TSH and anti TPO Ab. For supporting and clarifying the association between SLE and thyroid disorders in Iraqi, further studies on a large number of patients are required.

Acknowledgment I would like to express my special thanks and also the authors are grateful to to the staff of Baghdad teaching Hospital/ Medical city Iraq especially Dr. Ali Hussein Al-Hafidh for their kindness, generosity help in providing samples.

Ethical Clearance: The Research Ethical Committee at scientific research by ethical approval of both $\mathrm{MOH}$ and MOHSER in Iraq

\section{Conflict of Interest: Non}

Funding: Self-funding

\section{References}

1. Paul R, Raychaudhuri P, Sinha PK, Mookerjee S, Pandit K, Santra G. Prevalence of systemic lupus erythematosus among patients of hypothyroidism in a tertiary care center. Indian journal of endocrinology and metabolism. 2012 Jul;16(4):569.

2. Jenkins RC, Weetman AP. Disease associations with autoimmune thyroid disease. Thyroid. 2002 Nov 1;12(11):977-88.

3. Franco JS, Amaya-Amaya J, Anaya JM. Thyroid disease and autoimmune diseases. InAutoimmunity: From Bench to Bedside [Internet] 2013 Jul 18. El Rosario University Press.

4. Stathatos N, Daniels GH. Autoimmune thyroid disease. Current opinion in rheumatology. 2012 Jan 1;24(1):70-5.

5. Vanderpump MP, Tunbrldge WM, French J, Appleton D, Bates D, Clark F, Evans JG, Hasan DM, Rodgers H, Tunbridge F, Young ET. The incidence of thyroid disorders in the community: a twenty-year follow-up of the Whickham Survey. Clinical endocrinology. 1995 Jul;43(1):55-68.

6. Hadj-Kacem H, Rebuffat S, Mnif-Féki M, Belguith-Maalej S, Ayadi H, Péraldi-Roux S. Autoimmune thyroid diseases: genetic susceptibility of thyroid-specific genes and thyroid autoantigens contributions. International journal of 
immunogenetics. 2009 Apr;36(2):85-96.

7. Weetman AP, McGregor AM. Autoimmune thyroid disease: further developments in our understanding. Endocrine reviews. 1994 Dec 1;15(6):788-830.

8. Eguchi K, Matsuoka N, Nagataki S. Cellular immunity in autoimmune thyroid disease. Bailliere's clinical endocrinology and metabolism. 1995 Jan 1;9(1):71-94.

9. Hochberg MC. Updating the American College of Rheumatology revised criteria for the classification of systemic lupus erythematosus. Arthritis \& Rheumatism: Official Journal of the American College of Rheumatology. 1997 Sep;40(9):1725-.

10. Danchenko N, Satia JA, Anthony MS. Epidemiology of systemic lupus erythematosus: a comparison of worldwide disease burden. Lupus. 2006 May;15(5):308-18.

11. Kramer CK, Tourinho TF, de Castro WP, da Costa Oliveira M. Association between systemic lupus erythematosus, rheumatoid arthritis, hyperprolactinemia and thyroid autoantibodies. Archives of medical research. 2005 Jan 1;36(1):548.

12. Bombardier $\mathrm{C}$, Gladman DD, Urowitz MB, Caron $\mathrm{D}$, Chang $\mathrm{CH}$, Austin A, Bell A, Bloch DA, Corey PN, Decker JL, Esdaile J. Derivation of the SLEDAI. A disease activity index for lupus patients. Arthritis \& Rheumatism: Official Journal of the American College of Rheumatology. 1992 Jun;35(6):630-40.

13. Gladman DD, Goldsmith CH, Urowitz MB, Bacon $\mathrm{P}$, Bombardier C, Isenberg D, Kalunian K, Liang MH, Maddison P, Nived O. Sensitivity to change of 3 systemic lupus erythematosus disease activity indices: International validation. The Journal of Rheumatology. 1994 Aug;21(8):1468-71.

14. Borchers AT, Naguwa SM, Shoenfeld Y, Gershwin ME. The geoepidemiology of systemic lupus erythematosus. Autoimmunity reviews. 2010 Mar 1;9(5):A277-87.

15. Franco JS, Amaya-Amaya J, Molano-González N, Caro-Moreno J, Rodríguez-Jiménez M, AcostaAmpudia Y, Mantilla RD, Rojas-Villarraga A, Anaya JM. Autoimmune thyroid disease in $\mathrm{C}$ olombian patients with systemic lupus erythematosus. Clinical endocrinology. 2015 Dec;83(6):943-50.

16. Khanfir MS, Houman MH, Cherif E, Hamzaoui
A, Souissi S, Ghorbel IB, Ksontini I, Braham A. TULUP (TU nisian LUP us): a multicentric study of systemic lupus erythematosus in Tunisia. International journal of rheumatic diseases. 2013 Oct;16(5):539-46.

17. Ong SG, Choy CH. Autoimmune thyroid disease in a cohort of Malaysian SLE patients: frequency, clinical and immunological associations. Lupus. 2016 Jan;25(1):67-74.

18. Littlejohn E, Marder W, Lewis E, Francis S, Jackish J, McCune WJ, Somers EC. The ratio of erythrocyte sedimentation rate to $\mathrm{C}$-reactive protein is useful in distinguishing infection from flare in systemic lupus erythematosus patients presenting with fever. Lupus. 2018 Jun;27(7):1123-9.

19. Shimokaze T, Toyoshima K, Shibasaki J, Miyata M, Ohyama M, Kawataki M, Hoshino R, Itani Y. TSH suppression after intravenous glucocorticosteroid administration in preterm infants. Journal of Pediatric Endocrinology and Metabolism. 2012 Oct 1;25(9-10):853-7.

20. Zakeri Z, SANDOUGHI M. Thyroid disorder in systemic lupus erythematosus patients in Southeast Iran. Shiraz E Med J. 2010 11(1): 1-6.

21. El-Aziz A, Doma M, Mohammed AH, ElMoselhy EA. Thyroid Dysfunction andThyroid Autoantibodies in Egyptian Patients with Systemic Lupus Erythematosus (SLE). The Egyptian Journal of Hospital Medicine. 2018 Apr 1;67(1):482-90.

22. Chan AT, Al-Saffar Z, Bucknall RC. Thyroid disease in systemic lupus erythematosus and rheumatoid arthritis. Rheumatology. 2001 Mar 1;40(3):353-4.

23. Mader R, Mishail S, Adawi M, Lavi I, Luboshitzky R. Thyroid dysfunction in patients with systemic lupus erythematosus (SLE): relation to disease activity. Clinical rheumatology. 2007 Nov 1;26(11):1891-4.

24. Weetman AP, Walport MJ. The association of autoimmune thyroiditis with systemic lupus erythematosus. Rheumatology. 1987 Oct 1;26(5):359-61.

25. Pyne D, Isenberg DA. Autoimmune thyroid disease in systemic lupus erythematosus. Annals of the rheumatic diseases. 2002 Jan 1;61(1):70-2.

26. Al Saleh J, El Sayed M, Jassim V, Mohammed N, Khan N. Hypothyroidism determines the clinical 

and immunological manifestations of Arabs with lupus. Lupus. 2008 Mar;17(3):215-20.

27. Becker KL, Ferguson RH, McConahey WM. The connective-tissue diseases and symptoms associated with Hashimoto's thyroiditis. New England Journal of Medicine. 1963 Feb 7;268(6):277-80. 